\title{
Why Have-Nots Win in the HIV Litigation Arena: Socio-Legal Dynamics of Extreme Cases*
}

\author{
JANE HARRIS AIKEN and MICHAEL MUSHENO
}

\begin{abstract}
This study focuses on "extreme" cases, those in which "have-nots," usually people with HIV (PWAs), win HIV-related disputes in direct contests with "haves." Using extensive data gathered in the United States, we searched for a socio-legal explanation of how PWAs have managed to win claims against insurance companies, government agencies, and other institutional plaintiffs. We also looked at judicial preoccupation with PWAs as carriers of contagion. We have observed that PWAs win against haves when: their needs-based claims attract third parties with strategic interests and independent resources; and when litigators cause decision makers to identify with PWAs and employ proven scientific arguments to defeat fear of their clients' contagion. For example, gay activist lawyers devised such an effective strategy by defining $P W A s$ as persons with disabilities and by extending to them the antidiscrimination protections won earlier by disability rights' lawyers. While this approach brought relief in court for some and secured a less onerous identity for PWAs, its importance is diminishing with the shifting epidemiology of HIV in the United States.
\end{abstract}

\section{INTRODUCTION}

This study focuses on how a group of "have-nots," individuals and families living with HIV (PWAs), fare as parties to HIV-related litigation. Drawing upon a combination of focused interviews and 184 HIV-related, published

\footnotetext{
* We would like to thank Rebecca Bordt, Shari Diamond, Nancy Jurik, Frank Munger, Peter Tepley, and the anonymous reviewers for their insightful comments on previous drafts. Special thanks to Deborah Laake for her editing and Nancy Shealy for production support.

This research is supported by a NSF grant, Law and Social Science Program, grant number SES-8908456.

Address correspondence to Jane Aiken, School of Law, The University of South Carolina, Columbia, SC 29208.
} 
court rulings that are representative of the constitutive years of HIV litigation in the United States (1983-1989), we show that have-nots have gained access to the courts, usually pressing antidiscrimination claims against the state and private enterprise. In facing "haves" or institutional parties with substantial stakes in HIV, have-nots lose routinely in the appellate courts. Courts act to depoliticize the social tensions engendered by HIV by upholding the norms, routines, and interests of affected institutions.

While affirming the counterclaims of haves, courts reinforce and standardize the popular notion that PWAs are foremost "carriers of contagion" and thus endorse the idea that the way to control HIV is to control its carriers. The courts embrace the popular notion of PWAs as "others" threatening the mainstream population, and they show a great reluctance to affirm the needs-based claims of have-nots.

We also found, however, deviations from these central tendencies that appear only partly related to social classifications among PWAs. Children living with HIV are treated socially as "innocent victims," and this milder identity seems to allow them to win more often in court. At the same time, gay men, highly stigmatized in society, win with greater frequency than their stigmatized status would predict. The criminally accused and convicted living with HIV, also highly stigmatized, are far less successful than both children and gay men.

Given this variability in win rates among PWAs, what accounts for the occasional successes of have-nots? To explore this question, we looked at the influences of culture rather than exclusively at legal precedents. We view courts as political institutions and judges as political actors (see Danelski 1983; Sarat 1983; Kairys 1982). Judges make decisions according to classification systems (see Drass \& Spencer 1987; Levi 1949). Social and cultural conditions, historically grounded and specific to a particular social problem, shape the contours of such classification systems (see Smith 1988; Merry 1988; Laumann \& Knoke 1987). Also, judges have their own perspectives, hopes, fears, and experiences (see Henry 1985). Thus, prevailing social and cultural conditions shape rather than determine the classification systems employed by them.

We have found that PWAs win contests with haves when their needsbased claims attract supporters with strategy interests and resources, such as the ACLU, Lambda Legal Defense, and other rights-based organizations. Plaintiffs' causes are also helped by legal strategies that create identification between the PWA and the judge, and that use scientific arguments to defeat fear of their clients' contagion. These factors are evident in many of the cases PWAs win and at least one of these attributes is missing when they lose.

Our focus on the dynamics of extreme cases may aid groups that use law to struggle against dominant institutions and the "politics of otherness." At the same time, it offers insights into the limits of the courts as sites for resistance and social transformation, particularly for PWAs. 


\section{SOCIO-LEGAL DYNAMICS OF EXTREME CASES}

Have-nots win in litigation when they are able to overcome both social and cultural barriers. Without the participation of third parties with vested interests, have-nots lack the social standing (see Black 1976, 1984, 1989, 1990) and strategic resources (Galanter 1974; Wheeler, et al. 1987) to win against strong institutions. Specifically, Mather and Yngvesson (1980-81) point to the importance of "agents of transformation," or supporters, third parties, and audiences. As weaker parties attract supporting agents, they increase their power well beyond that available in their social status alone. Simultaneously, these third parties bring their own agendas to cases, transforming the disputes.

Most disputes are transformed through "narrowing" or "the use of established categories to organize the events and issues in dispute" (ibid., 783). A few disputes are "expanded": they produce new norms that challenge the conventional order. Thus, extreme cases, through the work of new alliances, may advance the interests of both PWAs and their agents.

Mather and Yngvesson suggest that language and its cultural messages are a strategic tool of these alliances. They emphasize a process of "rephrasing" or reformulating disputes (ibid., 777). Specifically, they argue that the expansion of a dispute is, in part, "a linguistic process in that changes in perspective and definition involve applying new labels to familiar persons and events" (ibid., 799). They note that women's rights activists concerned about wage discrimination create test cases that replace the conventional idea of "equal pay for equal work" with the expanded idea of "equal pay for work of comparable worth"; the latter expression points out that the gap in wages between genders is maintained because occupations are segregated by sex (ibid., 808). Mather and Yngvesson point to the specialized language plaintiffs use to stretch the legal concepts of "equal work" to encompass the notion of "equal value," or that jobs should be compensated on the basis of the skills they require.

Generally, the scholarship focusing on the cultural dynamics of case processing ${ }^{2}$ suggests that judicial opinions governing extreme cases are characterized by specific, repeated language. We expect that, in writing the opinion of an extreme case, a judge will use language that rejects dominant stereotypes of have-nots, that equates the behaviors of have-nots with that of members of "mainstream" society, or that compares the claims of havenots to the established claims of society.

\section{THE CONTEXT OF DISEASE SCARES}

Disease scares cause fear and conflict in many different kinds of institutions. Historically, legislatures and state agencies respond to disease 
scares first by blaming marginalized groups viewed as a threat to the establishment (see Nelkin \& Gilman 1988; Rosenberg 1988; Brandt 1987). This focus on marginalized people as threats to the mainstream provides a target for punitive action by governments while affirming dominant social institutions and established norms (see generally, Rosenberg 1988).

The U.S. courts have managed the disputes of all modern disease scares, including syphilis, cholera, and bubonic plague (see Bayer 1989). Their prevailing response has been consistent with the theory that the judiciary simply legitimizes dominant social and cultural orders. In managing the disputes of disease scares, the courts have accepted the designation of marginalized groups as carriers, have deferred to legislative authority, and have endorsed punitive measures without scrutinizing them (see Gostin 1987).

Simultaneously, evident in some judicial opinions is a counter-tendency to legitimize dominant responses to disease scares. As early as 1896 , judges showed interest in scrutinizing scientific evidence in order to sort out the effectiveness of state measures to control disease scares (Smith v Emery 1896). Also, McClain (1988) describes the importance of collective action combined with legal strategy that prevented the complete oppression of a minority during the bubonic plague scare of 1900 in San Francisco. He reveals the conditions that enabled Chinese Americans, a marginalized community identified as plague carriers, to block efforts to quarantine their community, and to gain judicial support. Specifically, he points to the organizational strengths of the Chinese community, their ability to garner resources, and the skills of their lawyers effectively to press test cases before a federal district court judge who then scrutinized state measures for effectiveness and fairness.

We see parallels between the response of the Chinese American community to the scare and the response of the gay community to HIV. In the late 1970 s and early 1980s, the United States was ignorant of HIV, a lethal virus that was infecting its population. Once the disease was identified in this country, it appeared primarily in the gay community and among intravenous-injection (IV) drug users. As the disease emerged in the public eye, much attention was paid to the social groups affected by the disease instead of the disease itself. It was as if becoming infected with the disease were simply a result of being gay or an IV drug user. Stigmatized groups became surrogates for transmissibility, considered "carriers of contagion." Instead of the disease being contagious, the people were contagious.

The gay community mobilized in response to the needs of gay people with HIV, and in recognition of the political threat to gays generally posed by the early construction of HIV as a gay disease (see Padgug \& Oppenheimer 1992). Their mobilization has been instrumental in altering institutional practices of both the medical and public health spheres (see Rothman \& Edgar 1992; Shilts 1987). 
AIDS has taken a devastating toll on the gay community and, at the same time, has provided strategic opportunity for enhancing its social legitimacy (see Altman 1987). Margaret Cruikshank, in her study of the influence of HIV on the gay liberation movement, notes:

Politicians who could ignore gay issues in the past cannot ignore the public health issue of AIDS, and they need the cooperation and expertise of gay organizations. Dead and dying men pushed gay life into the center of national political consciousness more dramatically than the living could have done.

(Cruikshank 1992, 185)

When evaluating why have-nots have won cases more than would be expected given their social status, we anticipate that gay mobilization has played a key role in accounting for the success of PWAs in the HIV litigation arena. Specifically, do the organizational strengths and strategic resources of the gay community provide litigious PWAs with strong, supporting agents, who litigate on their behalf, and who use the social and cultural dynamics of HIV to advance gay rights' interests?

\section{INTERVIEWS WITH GAY-ACTIVIST LAWYERS}

To explore this premise, we interviewed gay-activist lawyers in New York City who worked in civil and gay rights organizations, gay services agencies, private practice, the academy, and government (see Table 1). We focused on New York lawyers because a great deal of the early AIDS litigation was decided by state and federal appellate court judges whose jurisdictions included New York City and State. Also, New York-based civil and gay rights organizations were parties to AIDS litigation decided in jurisdictions throughout the United States.

We found that these litigators have shaped outcomes of much of the early HIV litigation. They were well networked and had clearly defined strategic

Table 1. Demographics of Interviewees Conducted in New York City during 1990

\begin{tabular}{clll}
\hline $\begin{array}{l}\text { Interview } \\
\text { Number }\end{array}$ & $\begin{array}{l}\text { Occupation/ } \\
\text { Position }\end{array}$ & Affiliation & Date \\
\hline 1 & Attorney & Government agency & 25 February \\
2 & Director & HIV-related community organization & 26 February \\
3 & Attorney & Private practice & 26 February \\
4 & Member & Social movement & 26 February \\
5 & Attorney & Civil rights group & 26 February \\
6 & Attorney & Private practice & 27 February \\
7 & Director & Gay legal rights organization & 27 February \\
8 & Attorney & Gay rights services organization & 27 February \\
9 & Attorney & Civil rights group & 9 October \\
\hline
\end{tabular}


agendas, often specifically focused on finding the "perfect plaintiff" before litigation was commenced. They used multiple strategies: legal, grass roots, and civil disobedience. They were responsive to the particular needs of PWAs, and they found among their clientele - primarily white, middleclass, and male - a group willing to engage in litigation. Finally, these lawyers knew the limitations of using law to achieve redress and educated their clients about these limits. These qualities contributed to the number of cases brought in the courts and the likelihood of success on the merits.

We found that gay-activist lawyers have developed effective local and national communication networks for AIDS-related litigation. For example, the director of legal services for a gay services organization told us that he serves as a point person for gay rights lawyers shopping for clients whose HIV-related claims coincide with the lawyers' desires to bring test cases to establish legal precedents that would be of assistance to PWAs. Such a network also allows clients to find lawyers willing to handle their cases. A gay-activist lawyer whose private practice focuses on HIV-related insurance issues describes turning to gay lawyers in New York City government when serious public issues surface through his practice:

I have a case right now that looked like a straight breach of contract dispute. A fellow thought he had disability coverage through his employment. He put in for benefits and was denied because he hadn't waited out the waiting period of his policy after he became employed. His agreement with his employer was that he was going to be put on all the plans right away, and so we sued the employer for having breached that promise. The employer has responded, claiming that this fellow misrepresented the state of his health. The response says that had he told them that he was HIV positive, they never would have hired him in the first place. This is, to me, prima facie employment discrimination. So, we asked colleages at the Human Rights Commission to come in on our side and they have agreed. (Interview number 3)

In addition to being well networked in the legal profession and highly focused on HIV-related legal issues, these lawyers are active in grass roots AIDS efforts in the New York gay community. One activist lawyer, employed by a national gay rights, public interest law firm, described stages of gay activism as first, providing services; second, coping with the legal issues; and finally, engaging in direct political action. In addition to his policy advocacy work for the firm, he was in ACT-UP, a "leaderless organization" that combines direct confrontation with theater, drawing on the skills of "middle-class gay white men who sell Madonna to America" (interview number 4). This multi-dimensional approach offers many possible solutions for problems related to HIV.

Most lawyers we interviewed said that gays in New York have responded assertively to AIDS, engaging in both political activity and litigation. The gay community being served was "middle-class, mostly white urban gay males" (interview number 2) unaccustomed to the degree of discrimination that their HIV status conferred. The director of legal services for a large, gay services agency said that the organization was originally a social services 
agency. After several months, it became clear that clients' legal needs were not being met, however, and thus the legal services of fice evolved:

When we started in ' 84 , most of what we were doing was drafting wills, power of attorneys, living wills, and taking care of that because life spans were so short. . . But as time has gone on, we are into a wider range of issues that have to do with living with AIDS. Now, we do a lot of discrimination work . . . most in the employment context. Also, because AIDS is so impoverishing, [we are] dealing with housing issues, trying to keep [PWA's] from being evicted, making sure people are using their insurance to the max, and getting the benefits they are entitled to. (Interview number 8)

A gay-activist lawyer working in city government said that in 1984 the Human Rights Commission added an AIDS division to cope with the many complaints filed mostly by white gay males (interview number 1). The activist attorney working in private practice suggested a reason for mushrooming complaints, saying that the gay community is so litigious about AIDS that he meets PWAs who think they have experienced health insurance discrimination when, in fact, they are being typically handled:

People call me up all the time and say "I put in a claim and the insurance company wants to speak to my doctor or see my doctor's records or they're delaying me in some way by doing this exam." In fact, any person who puts in an insurance claim, say for disability, is going to have to undergo that type of scrutiny of their medical records. But, people think it's because they're gay or because they have AIDS. Sometimes, the insurance companies have no idea. (Interview number 3)

The litigation initiated by these gay rights lawyers established the parameters of AIDS-related law in the United States. A gay-activist lawyer working in the gay rights project of a national civil rights organization views the school children cases - in which the courts reversed local school boards' decisions to isolate children living with AIDS - combined with those cases that extended disability protections to PWAs as "the central AIDS cases in which legal protections against discrimination were locked down" (interview number 5). Simultaneously, these lawyers recognize the limited scope of these precedents, particularly given the changing epidemiology of AIDS. The director of the premier gay rights law firm reflected on this dichotomy:

In the beginning, we dealt with principally discrimination issues. We litigated some of the first cases to apply disability statutes to people living with AIDS. Our focus is shifting, in part because there's at least a legal consensus that most of the forms of discrimination that we litigated do violate the law. . . The principal AIDS issue now is access to health care, particularly because, with the epidemiological shift, very poor people are getting disproportionately sick. . . . That's an area that's particularly difficult to litigate since economic rights are not, or are rarely taken seriously by the courts. We're doing what we can .... (Interview number 7)

These interviews establish that gay-activist lawyers, drawing upon their organizational and networking strengths, contributed crucial third-party 
support to PWAs, most of whom were litigious gays who, prior to contracting HIV, were middle-class professionals with strong gay identities. For many of the stricken, AIDS revealed their homosexuality to the "straight" community, particularly to employers, landlords, and insurance companies. Because of the stigma and the fear of AIDS itself, gays were oppressed and turned to the law for relief. Rather than devising a new, legal category, gay litigators stretched the meaning of persons with disabilities to include PWAs and won for their clients the benefits of existing antidiscrimination law. These interviews prompted our statistical analysis of our data and clarified the kinds of questions we used when analyzing the text of opinions.

\section{AGGREGATE ANALYSIS OF COURT CASES}

To explore the actual success of the lawsuits by PWAs, we analyzed 184 HIV-related cases published between 1983 and 1989, the formative period of HIV litigation in the United States. We employed a coding scheme analogous to the one adopted by Wheeler and colleagues $(1987,412-16)$. Specifically, we code parties as follows: individual litigants (PWAs); business parties (i.e., corporations, business proprietorships); and governmental parties (i.e., local, state, and federal agencies or units). We also code competing parties as either plaintiffs or defendants. Finally, we classify PWAs as criminally accused or convicted or IV drug users; gays; children or parent(s) of children; blood recipients or hemophiliacs.

We regard PWAs as weaker in society than either governmental or business parties. Also, we treat the criminally accused or convicted and gays as highly stigmatized while children or parent(s) of children and blood recipients or hemophiliacs are stigmatized only by having AIDS. Through this coding scheme, we use statistics to show how often classified parties engage in litigation, and to examine the relationship between the social standing of parties and how often they win.

\section{WHO LITIGATES WHAT AND WHO WINS}

PWAs have been able to push their lawsuits into state and federal appellate courts. They are the most frequent parties to HIV-related litigation, constituting one or both of the contesting parties in 174 of the 184 cases studied (see Table 2). Also they set the tone of most litigation, in that they are the plaintiffs in nearly 71 percent of the cases.

As plaintiffs, PWAs sue over a range of claims. Some focus on the loss or denial of work, housing, health insurance, and educational opportunities, and frame their claims as antidiscrimination suits. Others draw on antidiscrimination laws to contest isolation or denial of access to public resources, including public assistance. Still others oppose mandatory HIV testing or, in the case of voluntary testing, violations of confidentiality. 
While some plaintiffs address testing issues with antidiscrimination laws, others use the rationale of the right to privacy. While many PWAs use the courts to prevent restrictive acts of government agencies or private institutions, such as school children seeking access to schools, others use the courts to establish rights, such as access to the names of blood donors to determine the source of infection. Those seeking redress for infection have attempted to fashion remedies through the innovative use of tort law. Finally, a few PWAs denied access to medical services, filed unique claims related to a fundamental right to medical care, foreshadowing the current debate over universal health coverage.

Table 2. Frequencies of Plaintiffs and Defendants by Nature of Party

\begin{tabular}{lrrrr}
\hline & \multicolumn{2}{c}{ Plaintiffs } & \multicolumn{2}{c}{ Defendants } \\
\cline { 2 - 5 } Nature of Party & \multicolumn{1}{c}{$\mathrm{N}$} & $\%$ & $\mathrm{~N}$ & $\%$ \\
\hline PWAs & 130 & 70.6 & 44 & 23.9 \\
Businesses & 16 & 8.7 & 58 & 31.5 \\
Federal and state governments & 32 & 17.4 & 50 & 27.2 \\
Local governments & 6 & 3.3 & 32 & 17.4 \\
\hline Total & 184 & 100.0 & 184 & 100.0 \\
\hline
\end{tabular}

Wheeler and associates $(1987,187)$ find that individuals are generally the most active parties in the appellate courts, and they tend to press claims against other individuals. Regarding HIV-related litigation, PWAs are far more likely to press claims against haves, particularly governmental units and agencies (see Table 3). Yet, compared to governmental entities, they are far less likely to be successful as plaintiffs. Simultaneously, they have win rates comparable to businesses that initiate HIV-related litigation (see Table 3).

Tables 4 and 5 provide additional data about the win rates of individuals, governmental entities, and businesses; this data is consistent with measures employed by Wheeler and others $(1987,418-20)$. Specifically, Table 4 shows a combined success rate, including wins by each type of party. This measure of success shows that both businesses and governmental units or agencies win the majority of their cases while PWAs have a combined win rate of only 37.4 percent.

Because the combined success rate is affected by how often a category of parties initiates litigation as plaintiff, we calculated for each category a net advantage, or the success rate relative to the success rate of its opponents as plaintiffs. State and federal governmental plaintiffs have a significant advantage in the HIV-litigation arena. These findings mirror history, in which state institutions, particularly public health and criminal justice 


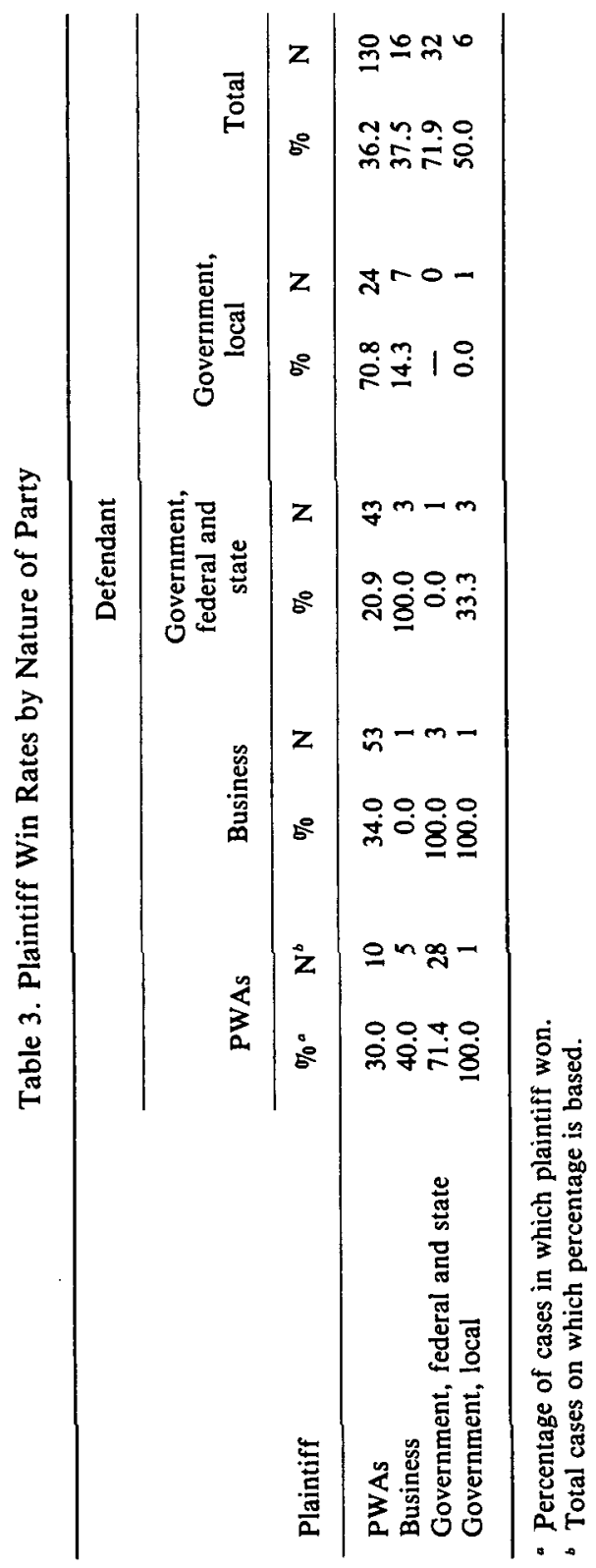


Table 4. Success Rates by Nature of Party

\begin{tabular}{|c|c|c|c|c|c|c|}
\hline Type of Party & $\begin{array}{l}\text { Success } \\
\text { Rate as } \\
\text { Plaintiff }\end{array}$ & - & $\begin{array}{c}\text { When } \\
\text { Defendant } \\
\text { Opponents' } \\
\text { Success Rate }\end{array}$ & $=$ & $\begin{array}{c}\text { Net } \\
\text { Advantage }\end{array}$ & $\begin{array}{l}\text { Combined } \\
\text { Success Rate } \\
\text { as Plaintiff } \\
\text { and Defendant }\end{array}$ \\
\hline PWAs & $\begin{array}{r}36.2 \\
(130)\end{array}$ & - & $\begin{array}{l}59.1 \\
(44)\end{array}$ & $=$ & -22.9 & $\begin{array}{r}37.4 \\
(174)\end{array}$ \\
\hline Business & $\begin{array}{r}37.5 \\
(16)\end{array}$ & - & $\begin{array}{l}37.9 \\
(58)\end{array}$ & $=$ & -0.4 & $\begin{array}{l}56.8 \\
(74)\end{array}$ \\
\hline $\begin{array}{l}\text { Government, } \\
\text { federal } \\
\text { and state }\end{array}$ & $\begin{array}{r}71.9 \\
(32)\end{array}$ & - & $\begin{array}{l}26.0 \\
(50)\end{array}$ & $=$ & +45.9 & $\begin{array}{r}73.2 \\
(82)\end{array}$ \\
\hline $\begin{array}{l}\text { Government, } \\
\text { local }\end{array}$ & $\begin{array}{r}50.0 \\
(6)\end{array}$ & - & $\begin{array}{l}56.3 \\
(32)\end{array}$ & $=$ & -6.3 & $\begin{array}{l}44.7 \\
(38)\end{array}$ \\
\hline
\end{tabular}

agencies, have dominated the management of disease scares, and the courts have deferred routinely to their authority. Local governments have no similar advantage, nor do businesses. Consistent with comparisons based on the combined success rate, PWAs win their claims less often than do their opponents.

Table 5 provides more detailed confirmation of the greater successes of haves in the HIV-litigation arena.

Still, PWAs do win. For example, Table 2 shows that PWAs win 70 percent of the cases when they sue local governments, while losing four out of five cases against state and federal governments. To account for the variability in win rates among PWAs, we began by narrowing the classifications

Table 5. Net Advantage for Different Combinations of Parties

\begin{tabular}{|c|c|c|c|c|}
\hline \multicolumn{2}{|c|}{ Combination of Parties } & \multicolumn{3}{|c|}{ Net Advantage } \\
\hline $\begin{array}{l}\text { PWAs } \\
\text { (18 of } 53)\end{array}$ & $\begin{array}{l}\text { vs. Businesses } \\
\text { ( } 2 \text { of } 5)\end{array}$ & \multicolumn{3}{|c|}{ Businesses by $6.0 \%$} \\
\hline $\begin{array}{l}\text { PWAs } \\
(9 \text { of } 43)\end{array}$ & $\begin{array}{l}\text { vs. Federal and state governments } \\
(20 \text { of } 28)\end{array}$ & \multicolumn{3}{|c|}{ Federal and state governments by $50.5 \%$} \\
\hline $\begin{array}{l}\text { PWAs } \\
\text { (17 of } 24)\end{array}$ & $\begin{array}{l}\text { vs. Local governments } \\
(1 \text { of } 1)\end{array}$ & \multicolumn{3}{|c|}{ Local governments by $29.2 \%$} \\
\hline $\begin{array}{l}\text { Businesses } \\
\text { ( } 3 \text { of } 3 \text { ) }\end{array}$ & $\begin{array}{l}\text { ss. Federal and state governments } \\
\text { ( } 3 \text { of } 3 \text { ) }\end{array}$ & \multicolumn{3}{|l|}{ Even } \\
\hline $\begin{array}{l}\text { Businesses } \\
(1 \text { of } 7)\end{array}$ & $\begin{array}{l}\text { s vs. Local governments } \\
\text { (1 of } 1)\end{array}$ & \multicolumn{3}{|c|}{ Local governments by $85.7 \%$} \\
\hline \multicolumn{3}{|c|}{$\begin{array}{l}\text { Plaintiff success rate for dominant plaintiffs } \\
\text { Plaintiff success rate for subordinate plaintiffs } \\
\text { Net advantage for dominant plaintiffs }\end{array}$} & $\begin{array}{l}28 \text { of } 38 \text { cases } \\
49 \text { of } 138 \text { cases }\end{array}$ & $\begin{array}{r}=73.7 \% \\
=35.5 \% \\
\quad 38.2 \%\end{array}$ \\
\hline
\end{tabular}


Table 6. Plaintiff and Defendant Win Rates by Type of Individual

\begin{tabular}{lrrrr}
\hline & \multicolumn{2}{c}{ Plaintiffs } & \multicolumn{2}{c}{ Defendants } \\
\cline { 2 - 5 } Type of Individual & $\%^{\circ}$ & $\mathrm{N}^{c}$ & \multicolumn{1}{c}{$\%^{\circ}$} & $\mathbf{N}^{c}$ \\
\hline Gay & 60.0 & 5 & 85.7 & 7 \\
Prisoner/accused/IV drug user & 17.5 & 41 & 29.2 & 24 \\
Child & 64.7 & 17 & - & 0 \\
Blood recipient & 21.1 & 19 & 100.0 & 1 \\
\hline
\end{tabular}

- Percentage of cases in which plaintiff won.

- Percentage of cases in which defendant won.

c Total cases on which percentage is based.

of PWAs engaged in litigation, and by investigating whether differences in the social status between groups of PWAs accounts for the variation. Table 6 shows that we were able to narrow the classifications of PWAs in 114 of the 174 cases in the sample. Also, it shows that criminally accused or convicted PWAs are most likely to press HIV-related litigation in court.

While accused criminals and prisoners are the most litigious PWAs, this group is the least likely to win (see Table 7). They are highly stigmatized and are often suing powerful state agencies, so that they lose routinely. Also, consistent with Black's (1984) notion that law varies according to social status, Table 7 shows that the most successful PWAs are children - "innocent victims" - suing local governments, usually local school boards. However, this table also shows that degree of stigma does not account fully for the variation in win rates among groups of PWAs. Specifically, blood recipients and hemophiliacs, also "innocent" victims, lost most early cases against the blood industry. ${ }^{3}$ And gays who are highly stigmatized, tend to win against businesses and governments.

\section{QUALITATIVE ANALYSIS OF CASES}

Our interviews offer at least one explanation for the different win rates among PWAs. Both gay PWAs and children with HIV received substantial third-party support from gay-activist lawyers, their organizational affiliations, and activists' alliances with others, particularly disability rights lawyers. Gay-activist lawyers also told us, however, that they have supported some criminally accused and convicted PWAs and have had much greater difficulty winning on their behalf (interview number 5).

Support from gay-activist lawyers may not completely explain the relative success of PWAs, however. To explore whether and how language and its cultural messages are a strategic tool that affect the wins of PWAs, we began by reading a set of cases with a low win rate - those involving the 


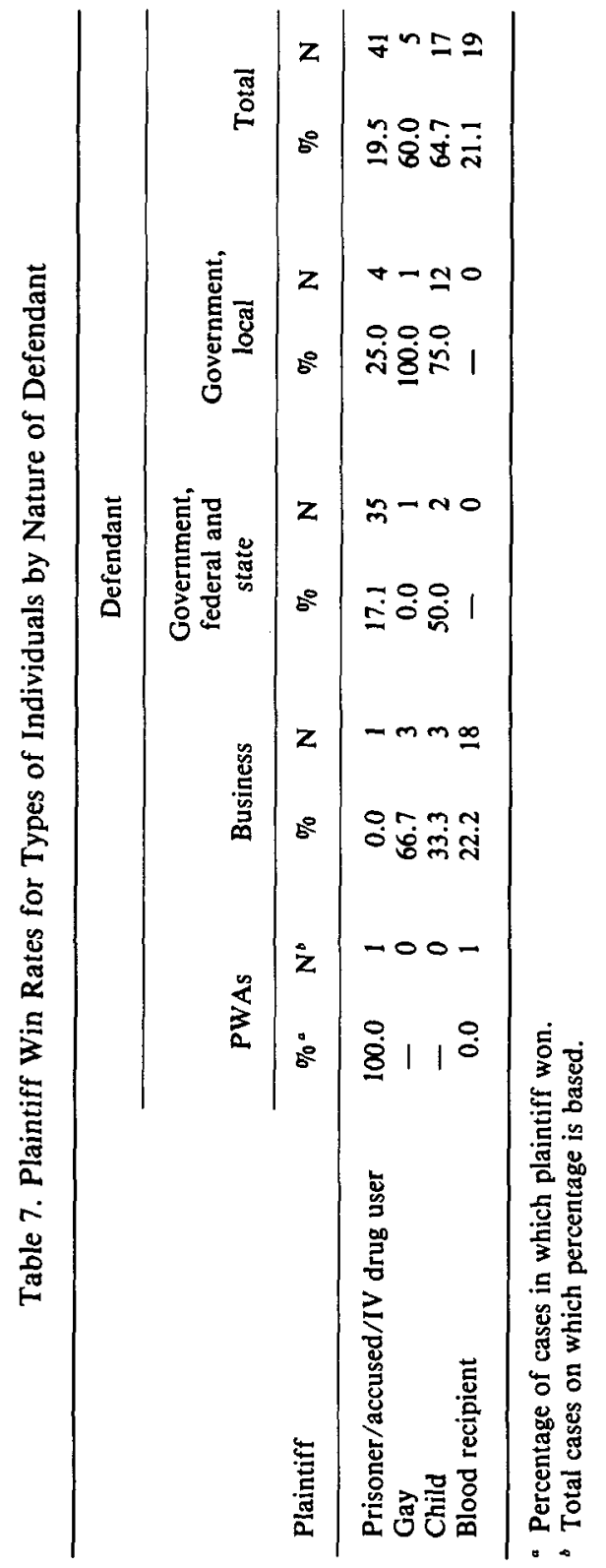


prisoners. Although we analyzed the cases traditionally - as a source of data - we did not concentrate primarily on how case outcomes are affected by the facts of the cases combined with legal doctrines. Instead, we built upon Levi's (1949) ideas about judicial reasoning, wherein judges reach decisions by applying classification systems rich with social and cultural meaning to decide what facts should be privileged and which doctrine should be applied in particular cases. Specifically, we analyzed the language of judicial opinions, the characteristics of litigants, and the construction of competing claims, to infer whether the courts acknowledge the social status of parties and adopt the prevailing cultural view that PWAs pose a threat to the mainstream public.

Do we find consistent evidence of judicial bias against the stigmatized when the courts reject the claims of the prisoners? The analysis of the prisoner cases shows that social status colors the evaluation of the medical evidence and the weight given to the claimed need or deprivation. Also, we reveal the strong effect of social status by contrasting the cases involving prisoners with the cases where school children are parties to HIV disputes.

To explore further the combined effects of social and cultural conditions at work, we concentrated on the two sets of litigants with high win rates children and gays. Again, we analyzed each case for the social characteristics of the litigants and the language of the opinions. We inferred whether judges latched onto plaintiffs' strategic messages that upholding their claims would pose no threat to the mainstream public or would actually serve the general welfare. Or, did judges ever adopt those interpretations on their own in order to justify their rulings? When either of the above occurred, was there support from third parties? Did accompanying judicial opinions contain language that rejected the cultural stereotypes of PWAs? Did these opinions cite scientific evidence to dispel the fear of the contagion of AIDS?

\section{A. RESTRICTIONS ON PRISONERS}

The cases involving prisoners confirm the strong effect of social status on outcome. Our society views prisoners as vectors of social problems. It is not surprising that incarcerated persons were some of those oppressed very early in the history. of HIV. Prisoners have been involuntarily tested, segregated, and clearly identified within the prison community as HIV positive. Numerous prisoners have challenged these restrictions. Most prisoners bringing claims do so without the assistance of a lawyer. These cases highlight the significance of social status, exaggerated notions of contagion, and what happens when PWAs lack third-party assistance. On the whole, prisoners, who usually initiate their own cases, lose no matter what they claim. ${ }^{4}$ In cases upholding the segregation of HIV-positive prisoners, the fear of disease spreading inside the prison was the primary justification cited (see Powell v Dep't of Corrections, State of Oklahoma 
1986). The potential for spread was sufficient; litigants were not required to show that an individual had or was engaging in behavior likely to spread the virus (Judd v Packard 1987).

In Doe $v$ Coughlin $(1986,1987)$, a New York prisoner with AIDS sought a conjugal visit with his wife through the Family Reunion Program. This program was designed "to preserve, enhance, and strengthen family ties that have been disrupted as a result of incarceration" (Coughlin 1987, at 51). The visit was denied, even though both husband and wife had been counseled about how AIDS is transmitted and had had a conjugal visit before the prisoner's diagnosis. Apparently, the opportunity for unsafe sex was not the only concern prompting prison officials: the prisoner's requests for overnight visits with family members who were not sexual partners were also denied. The court upheld the denial of visitation, saying it was a rational response to the potential for HIV transmission. We believe that the difference in social status between the court and the prisoner facilitated an exaggeration of the risk of contagion and justified oppressive treatment:

The crucial point is that respondents cannot guarantee that the AIDS virus will not be transmitted should petitioners be allowed to participate in the Family Reunion Program, regardless of whether they engage in sexual contact. . . . Moreover, while epidemiologic studies of families of AIDS patients and health-care workers speak against transmission through casual contact. . . , the possible risk of transmission from close contact with an AIDS sufferer remains an unresolved question of great concern. Nor, as a practical matter, are respondents adequately equipped to scrutinize the hygiene of the facilities of the Family Reunion Program. (Coughlin 1986, at 786)

When dealing with "innocent victims," however, the courts have behaved very differently: they have refused to allow mere medical possibilities or unresolved concerns about the transmissibility of HIV to control the outcome of lawsuits. The medical evidence in the above case was virtually identical to the medical evidence offered in cases involving school children, but in the latter, the medical evidence was rejected as a justification for restrictions. $^{5}$

Many claims arising from prison segregation procedures involve the potential stigma of HIV isolation, which has ramifications both within and without prison walls. In virtually all cases in which prisoners challenged segregation policies, courts failed to give credence to the concern with stigma and focused instead solely on the need to contain the disease.

This willingness to ignore medical facts when prisoners are plaintiffs also appears in Judd $v$ Packard (1987). When a prisoner was placed in hospital isolation units while being tested for HIV, he, without a lawyer, brought a claim alleging a violation of his constitutional rights. He argued that segregation was not necessary given the medical evidence on the potential for HIV transmission. Therefore, isolation was unwarranted and violated his rights. The court found no constitutional infringement, saying the prisoner had no right that had been violated. 
In Judd, the court ignored a prisoner's decision to avoid isolation and focused on the potential for transmission within the prison. The opinion stated that AIDS poses an "unprecedented danger to public health," and has the potential for "causing a plague of (or beyond) Biblical proportions," concluding that the danger was heightened in the closed prison community, where the virus could be transmitted "whether wittingly or unwittingly to other inmates, through homosexual encounters or otherwise" (ibid., at 743). Throughout the opinion, the court distanced itself from the pro se plaintiff by describing him as an escapee, identifying him as HIV infected, and referring to such infected individuals as "carriers.". This evaluation allowed the court to grant prison officials absolute discretion in dealing with potential HIV "carriers."

The prisoner cases demonstrate the influence of status on the evaluation of medical evidence and the consideration of harm. The social distance between the judicial decision maker and the prisoner allows the "medical uncertainties" about HIV to justify oppressive treatment and stigmatizing isolation. Furthermore, prisoners often lack legal counsel and effective third-party assistance and cannot challenge the use of such medical evidence or offer competing medical expertise. These factors, combined, appear to influence the consistently negative outcome in court cases brought by prisoners with HIV.

\section{B. SCHOOLCHILDREN}

By contrast, mere possibilities of transmission are not given credence when dealing with children. Schools, like prisons, are closed communities with many of the same concerns about the potential transmissibility of disease. In the school cases, the possibility of transmission is often offered as evidence to justify segregation of school children with HIV, but the courts have consistently rejected such speculation. Unlike the prisoner cases, the school children cases used substantial medical evidence, often with competing experts. ${ }^{6}$ Perhaps this difference was due to the third-party support and resources that the children, unlike their prisoner counterparts, were often able to attract in their claims against counties and school boards. The difference may also be due to the lack of social distance between the child and the decision maker, thus allowing for a more balanced hearing on the issues.

The school children cases of ten outline how the child became infected and the facts are recounted in a very sympathetic voice. One opinion begins its conclusion by outlining the problem:

A preteen grade school student, an innocent victim of a disease generally considered fatal, asks the court to exercise its historic equitable powers to sever the strictures of individualized "homebound" education and return him to his classmates and a normal school situation. (Doe $v$ Dolton Elementary Sch. Dist. No. 1481988 , at 449) 
This description is a stark contrast to the descriptions in the prison cases: here the party asserting the claim is an "innocent." The plaintiff is not asking the court to disrupt the status quo but is drawing on the court's timehonored role: to ensure that when the status quo is disrupted, it is done for good reason and that rights are not violated in the process. Similarly, in Ray v School District of DeSoto County (1987), the court analyzed the public's interest in segregation of HIV-positive children. It stated:

The children of this state include children like the Ray boys, who, through no fault of their own, have contracted this disease; it clearly provokes in many, fear and a desperate desire to segregate them from mainstream life. (Ibid., at 1535)

Once again the court appeals to the notion of innocence; such innocence appears to have an effect on how the court views the medical evidence. Unlike the prison cases, courts in the schoolchildren cases will not allow the potential for theoretical harm to justify segregation.

A Florida case, Martinez by and through Martinez $v$ School Board of Hillsborough County, Florida, best demonstrates the differing use of the same medical evidence on transmissibility. A U.S. district court evaluated the medical literature and found a theoretical risk of transmission through the urine, tears, and saliva of an HIV-positive child who sought to attend regular classes. Because of that risk, deemed "remote" by the judge (Martinez I 1988), the court ordered that the child be placed at a distance from her classmates in a specially constructed room connected to the regular classroom.

The Court of Appeals for the Eleventh Circuit vacated and remanded (Martinez II 1988), finding that the risk posed by urine, tears, and saliva was not of the "significant risk" level required by federal law before the child could be excluded from the classroom. On remand, the district court reiterated that there was divergent medical opinion and testimony (Martinez III 1989). However, this time the appropriate "significant risk" standard was used and the court found the theoretical risk not sufficient to justify the segregation.

The effect of stigma and social distance for prisoners as compared to schoolchildren is further illuminated by the different ways the harm principle has been applied. Unlike the prison cases, in which the harm of segregation is rarely evaluated, the schoolchildren cases often focus on that concern. In Doe v Dolton Elementary (1988), the court details all of the lost benefits for a student forced to receive an education at home instead of at school. In addition to particular losses, the court also examines the stigma of such segregation, referring to time-honored and respected precedent.

The stigma attached to Student \#9387 is even greater considering the increased negative importations associated with AIDS. . . . [I]f AIDS-infected children are segregated, they will suffer the same feelings of inferiority the Supreme Court sought to eradicate in Brown [v Board of Education] 34 years ago. (Ibid., at 447) 
The difference in outcome between the schoolchildren and the prisoners' cases is attributable to the status of the parties and the social distance between the party and the decision maker. But what of the gay litigant? Gay men are stigmatized, yet our research reveals a disproportionate number of cases than would be predicted in which gay men win lawsuits against institutions. Through the gay cases, we identified the full set of characteristics that appear to be necessary and sufficient for success in HIV litigation.

\section{GAYS}

Our analysis of these cases revealed that a combination of litigation strategies and litigation support allowed the courts to overcome tendencies that were so apparent in the prisoner cases. Yet not all of the gay cases have been successful. The cases in which the gay litigant loses demonstrate the effect on case outcome of social distance and the association of contagion with risk groups made up of marginalized people.

As an initial response to the epidemic, public health agencies invoked police powers "to curb the spread of the disease." Restrictive measures were directed toward gays and places where gays congregated. Some of the earliest HIV cases focused on the closing of gay bath houses. These claims raised first amendment, right to privacy, and freedom of association challenges to the wholesale closure of gay bath houses and restrictions on gay bookstores (City of New York v New Saint Mark's Baths 1986). Normally, when protected rights are at stake, government is held to a standard of showing that its action is the least restrictive alternative available to achieve the stated goals. That standard was relaxed when applied to the closure of gay baths.

In New Saint Mark's Baths, the health commissioner found that public health intervention was essential to "interrupting the epidemic among the people of the State of New York" (1986, at 914). The commissioner used the state's nuisance laws to close the facility after an investigation revealed that numerous acts of unsafe sex were occurring on the premises. The defendants challenged the scientific determination that the baths caused the spread of AIDS, citing the previous health commissioner's finding that closing the baths would contribute little or nothing to the control of AIDS. They claimed that the baths could educate many individuals in the gay community who might be at risk for HIV about disease and prevention. They also argued that closing the baths did nothing to prevent unsafe sex acts and that a less restrictive alternative would be to make condoms and HIVeducational materials available to all clientele. The gay community divided on the issue of whether to close the baths (Shilts 1987). The defendants received no third-party support from rights organizations in their challenge to the closings.

Rejecting the defendants' arguments, the court upheld the commissioner's act as a legitimate exercise of the police power. The opinion began with the 
medical facts, which focused on the "risk groups," noting that 73 percent of those persons who had died of HIV were "sexually active homosexual and bisexual men with multiple partners." Instead of noting that unprotected sex spreads the disease, the court said: "Cases of AIDS among homosexuals and bi-sexual males are associated with promiscuous sexual contact" (New Saint Mark's Baths 1986, at 912; emphasis added). This language marginalized and stigmatized the persons seeking to keep the baths open. ${ }^{7}$ This case confirmed one strong social influence on AIDS litigation also present in the prisoner cases: the greater the social distance between the claimant and the decision maker, the less likely a favorable outcome.

Social distance and a concern about transmission to the mainstream population also affected the outcome in an early case involving HIVpositive health care workers. A federal district court upheld the dismissal of a nurse, Kevin Leckelt, who refused to reveal his own HIV test results, stating that knowledge of the test results of health care workers was a necessary first step in protecting patients (Leckelt $v B d$ of Comm'rs of Hosp. Dist. No. 1 1989). The rules of the hospital where Leckelt worked required all employees who thought they might be infected with a communicable disease to have themselves tested, notify their superiors of the results, and use appropriate methods to prevent transmission of the disease. In the case of Kevin Leckelt, the hospital required him to be tested after learning that his roommate had tested positive for HIV and had been treated in the hospital. Kevin Leckelt was presumed to be a homosexual. Kevin Leckelt challenged his firing as discrimination on the basis of a handicap. The court held that he was fired for failing to follow the rules required of all employees and not because of a handicap.

Despite the finding that Mr. Leckelt had violated the hospital's rules, the court went on to consider the handicap claim. The court said that under the 1973 U.S. Rehabilitation Act, Kevin Leckelt would not be found to be "otherwise qualified" for his position even though any possible infectiousness could be significantly reduced through the use of universal precautions. The court stated: "Hospitals are not at liberty to presume, at the risk of the lives of the public, that all employees adhere to their infection control policies at all times" (ibid., at 1387). This finding was inconsistent with Centers for Disease Control and Prevention guidelines about HIV-positive health care workers now promulgated by the Occupational Safety and Health Administration (1991); and the finding contradicted medical evidence that indicates an extremely low risk of communicating HIV from health care worker to patient (CDC 1991).

Leckelt marshalled a great deal of third-party support on appeal including Lambda Legal Defense, the AIDS Legal Council of Chicago, the American Public Health Association, and the American Society of Law and Medicine. The circuit court affirmed on the basis that Kevin Leckelt had violated the hospital rules. The opinion includes substantial medical evidence on the proper treatment of HIV-positive health care workers that 
undermines the trial court's opinion about the lack of usefulness of universal precautions. The trial court's exaggeration of the risk of HIV transmission is consistent with the exaggerated evaluation of risk in the criminal setting. The assessment of risk has also been overstated when courts dealt with HIV-positive dental or medical students. ${ }^{8}$ This case suggests that social distance is not the only social factor affecting determination: the fear of transmission to the mainstream public through the health care system may contribute to the courts' willingness to overstate the risks. ${ }^{9}$

Despite the fear of transmission and social distance associated with homosexuality, what accounts for the aggregate data that indicate that gay litigants win a number of their claims against institutional parties? We suggest that a combination of social and cultural attributes influences their success. Third parties provide strategic resources and devise ways to close social distance using litigation strategies that present the claimant as a living, breathing person, recognizable to the decision maker. The fear of transmission is lessened by medical evidence presented after the claimant is made more personal or after the issue is argued as analogous to other more "mainstream" legal problems.

Third-party support was evident in one of the early employment discrimination cases that established HIV as a protected disability. Using state laws, the National Gay Rights Advocates brought against Raytheon Company one of the first employment discrimination cases. The company had refused to allow a quality control analyst to return to work after it was discovered that he was HIV positive. The upper management believed, despite medical evidence, that he could casually communicate the virus. The litigation strategy focused on the fact that HIV should be treated like any disability, and that only if that disability interfered with job performance should it be a reason for firing or transferring an employee.

The California Employment and Fair Housing Commission found that Raytheon had discriminated on the basis of physical handicap, thus clarifying that people with HIV were protected under state law. The commission ordered reinstatement and back wages, and it required the employer to post notices about employee rights and to provide workplace education about HIV. The commission's order was affirmed on appeal (Raytheon Co. v Fair Empl. \& Housing Comm'n 1989). Given the financial disparities between the employee and Raytheon, it appears that without the support and persistence of gay rights organizations, i.e., Lambda Legal Defense, Gay Men's Health Crisis, the American Civil Liberties Union, and other organizations, this case would not have pushed forward to establish that persons with HIV were to be viewed as persons living with disabilities.

Another factor that we hypothesized influences outcome is the degree to which the decision maker can identify with and understand the claimant. Because of the gay community, this factor has taken a surprising twist with AIDS. HIV has been closely linked to homosexuality in the public's mind (more so than the epidemiology merits) and thus has required the dominant 
culture to come in contact with gay people and their concerns in ways that have been avoidable in the past. Approximately 60 percent of the HIV lawsuits brought in this country involve gay and bisexual men (Slind-Flor 1990), with the result that judges cannot avoid seeing gay men's lives and noticing the (surprising) similarity to their own. As judges deal with HIV, they confront the stereotypes that have provided them with comfort and simultaneously forced invisibility on the gay community. In particular, judges see committed partners supporting their gay mates through devastating illness and death, and that this picture looks remarkably like what the court expected from straight married couples.

Recognition of committed gay partners as a family occured in Braschiv Stahl Associates Co. (1989).10 Miguel Braschi nursed his lover, Leslie Blanchard, through his death from AIDS. They shared a rent-controlled apartment in New York City that was leased in Blanchard's name. Upon Blanchard's death, the landlord moved to evict Miguel Braschi because he had no legal relationship to the tenant of record. Braschi sued asking the court to expand its view of family. He was assisted in his litigation by the ACLU. The court found that the term "family" should not be restricted to those with formal evidence of it, such as a marriage license or adoption order. Instead, the court said that a more appropriate definition of family status would evaluate factors such as financial commitment, the exclusivity of a couple's relationship, and mutual reliance. The positive outcome in the Braschi case was influenced by the presence of significant third-party support and a litigation strategy that both enhanced the identification between the decision maker and the claimant, and that used the mass media to spread the word that many gay couples were struggling against discrimination while coping with serious illness.

In some cases, like Braschi, the facts themselves help create identity with the decision maker. In other cases, the litigant includes extra facts in the pleadings that ensure identification. In Yorkshire Towers Co. $v$ Harpster (1986) three gay-life partners of tenants with leases to rent-controlled apartments pressed the court to stretch the notion of family member to include their relationships when their partners died of AIDS. They filed suit to thwart their landlord's attempts to evict them. The landlord countered, citing the "roommate law," which allowed the eviction of any roommate not on the lease if the tenant left the apartment for any reason. Each claimant submitted an affidavit that drew specific parallels between his relationship and those of a traditional straight couple. One of the partners wrote: "I am unable to adequately convey the profound loss Dennis' death has had upon me. I have experienced this loss in the same way a widowed spouse would" (ibid., at 386). Another said, "Rene and I resided in the apartment as a couple . . . like any married couple, we shared household responsibilities, including all domestic chores" (ibid., at 387). The court ruled in favor of the gay men, noting that its decision was consistent with the city policy of not discriminating on the basis of sexual preference, ${ }^{11}$ and 
that to do otherwise would violate equal protection, because the court recognized unmarried heterosexual couples.

Third-party support helps ensure that such identity is effectively put before the court. These groups draft briefs and use discovery and the media to flesh out the person with HIV so to make him more recognizable to the court. For example, in Chalk v U.S. District Court for the Central District of California (1987), the court granted Vincent Chalk ${ }^{12}$ a preliminary injunction forbidding the Orange County Department of Education (the department) to force him out of the classroom. A teacher of hearingimpaired students, Vincent Chalk had been reassigned to administrative duties after he confided to a co-worker that he had AIDS. The department claimed that Chalk posed a risk of harm to others, either medically or through the fear of his presence. The department introduced a medical expert who claimed, "there is a probability, small though it is, that there are vectors of transmission as yet not clearly defined" (ibid., at 707).

Despite this medical evidence and Chalk's status as a gay man, the court granted a preliminary injunction, finding that the request for protection against employment discrimination under section 504 of the Vocational Rehabilitation Act was likely to succeed on the merits. More remarkable, the court rejected the contention that because Vincent Chalk had been reassigned without loss in pay rather than fired, there was no irreparable injury that required immediate injunctive relief. The court said:

His closeness to his students and his participation in their lives is a source of tremendous personal satisfaction and joy to him and of benefit to them. ... Such non-monetary deprivation is a substantial injury which the court was required to consider. (Ibid., at 709)

The court found that the department's argument that reassignment was necessary to deal with the children's fear of HIV was unjustified, and the reaassignment was unreasonable. The decision showed compassion for and acknowledgement of Vincent Chalk as a whole being instead of reducing him to a vector of disease. The record is replete with descriptions of Chalk's dedication to teaching to his students and with medical evidence indicating the lack of transmissibility in this setting. Vincent Chalk received significant third-party support from the ACLU of Southern California in his litigation; the court accepted numerous amicus briefs in support of Chalk. ${ }^{13} \mathrm{We}$ suggest that this litigation support, a focused strategy of making Vincent Chalk "real and recognizable" to the judge, not merely a "carrier" of contagion, and the supporting medical evidence, caused the positive result in this case despite his stigmatized status.

\section{STRATEGIC IMPLICATIONS}

The aggregate analysis of cases showed that who the parties are is the single most important factor in any court contest. Dominant parties, usually institutions with profits or their authority on the line during litigation, win 
routinely. Claimants - such as IV drug users, sex workers, persons accused or convicted of crimes, or gay men characterized as sexually active - all are burdened by social stigma and lack social standing, and they lose with greater frequency.

The qualitative analysis of cases showed that judicial decision makers distance themselves from people with HIV, use them as symbols of contagion, and endorse the view that the way to control HIV is to control those persons who have or are perceived to have the virus. It is only when this underlying configuration of social and cultural conditions is confronted and neutralized in the development of the case that PWAs can win with regularity.

As revealed in our interviews, gay-activist lawyers used their networks and alliances with other rights organizations to secure strong third-party support for some PWA litigants, particularly gays and children living with HIV. Rather than devising a new category of discrimination, they latched onto antidiscrimination laws secured for people with disabilities and stretched the meaning of disability to include people with HIV. To stretch this meaning, it was necessary to defeat the popular cultural view of PWAs as carriers. Our qualitative analysis reveals that involved third parties did this by creating identity between the litigant and the judicial decision maker, and by making effective use of the growing medical discourse about the transmission of HIV. We identify the litigation strategies below.

\section{A. IDENTIFICATION WITH THE LITIGANT}

Increasing personal identification with a PWA makes it less likely that the PWA's claim will be rendered invisible. Forcing the judge to view "closeup" the person with HIV may diminish the symbolism of HIV and inspire compassion toward PWAs. If this happens, persons with HIV have a greater chance of winning in court.

Litigators used several tactics to confront the tendency of judges to view people with HIV as disposable members of society. One was the use of analogy: problems arising in the HIV context were compared to other, less stigmatized, conditions familiar to the courts, for example, equating HIV with other disabilities or diseases afforded protected status (interviews number 7 and 9). When dealing with health care reimbursement schemes, litigators have compared HIV to cancer in order to gain access to life prolonging drugs. ${ }^{14}$ The cases involving access to education for children offered the easiest routes for judicial identification. These children were often specifically called "innocent victims" and that appealing status may have contributed to the quick establishment of legal precedent that discrimination in access to education on the basis of HIV was illegal.

Even for those parties who cannot access the vehicle of "innocent victim," revealing behavioral patterns consistent with the dominant culture is another strategy to counter the politics of "otherness." This is done when 
attorneys choose their particular plaintiffs, through down playing the stigma of HIV, exploding stereotypes, and focusing on admirable qualities or similarities between PWAs and the dominant culture. For example, in Braschi, the plaintiff was presented as a compassionate spouse of a terminally ill mate and a respected member of the community who held a regular job.

It is not unusual for litigators to look for the "perfect plaintiff," an aggrieved party with whom the court could identify. In the HIV arena, the characteristics of the plaintiff may be even more important. If advocates can inspire courts to perceive the aggrieved party as a full human being inconsistent with the cultural stereotype, the chances for legal relief also improve. It is, therefore, not surprising that in New York City and San Francisco, where the judiciary is more likely to know and interact with gays, HIV litigants are having greater success. ${ }^{15}$

\section{B. TRANSMISSION OF HIV TO THE MAINSTREAM POPULATION}

Third-party supporters have needed to persuade judges that protecting the civil rights of PWAs would not endanger the health of the "mainstream" white heterosexual population. As part of litigation strategy, third parties have used scientific data and expertise as a specialized language of medicine to recognize the judge's concern about the epidemic's spread while simultaneously extending the rights of people with HIV.

Scientific language was not always used neutrally by courts. In criminal cases, the courts employed medical arguments not reflective of true knowledge of the epidemic to exaggerate the risk of transmission and justify oppressive treatment of HIV-positive individuals who were prisoners or accused of crime. In the school cases, including those in which the behavior of children and prisoners is similar (e.g., biting others, closed communities), the courts used medical arguments to support the claims of children with HIV. In order to counter the misuse of medical evidence, therefore, it is not sufficient merely to produce the medical evidence. Simultaneously, litigators adopt additional strategies to establish identity between their HIVpositive clients and the judiciary. ${ }^{16}$

\section{POLICY IMPLICATIONS}

The activist lawyers we interviewed in 1990 all agreed that the body of law covering HIV litigation is largely developed - that is, that the contours of antidiscrimination law are in place for PWAs. Although HIV disease mobilized gay communities throughout the United States, it did so desperately. Many urban, gay professionals became ill, and the fear of AIDS marked all out gays as potential carriers. HIV litigation, undertaken by gay-activist lawyers with their own agendas, is one manifestation of this mobilization. It 
was pursued to block legal oppression of urban, professional gays and, as a result, a substantial body of law was established to blunt discrimination in the workplace and in housing, and to enable gays with health insurance to retain their benefits. Moreover, the success of gay litigators and their allies depended upon their abilities to personalize the identities of PWAs, so that they are transformed from carriers of contagion into people with disabilities. By doing so, litigators secured public assistance for many PWAs while leaving the private, for-profit health care system intact.

Simultaneously, these lawyers recognize that this body of law may become outdated as the epidemiology of HIV shifts, affecting vast numbers of poor people of color and IV drug users who are highly marginalized. With this shift, the factors we identified as contributing to the success of marginalized groups in litigation, will become unavailable. We predict that there will be a reduction in third-party support, and even if supporters come forward, a reduction in the ability to create identity between the judge and the claimant. Furthermore, the type of claims has changed from rights based to resource based. These problems are not best resolved in the courts. One of the activist lawyers reflected upon the effects on litigation of the shifting epidemiology of HIV:

The dominant issue now in New York is access to health care, particularly because, with the epidemiological shift in New York, very poor people are getting sick [with HIV] disproportionately. These are people who rely on the City and the State of New York for their health care and the City and State are not reliable care providers. I would love to construct a lawsuit that would make a claim that people with AIDS are entitled to a primary care doctor in New York and elsewhere. But, trying to construct such a suit these days is almost impossible. We visit the question from time to time and have talked to other organizations about the possibility of doing it, but economic rights are generally not recognized. (Interview number 7)

Others echoed these sentiments, arguing that "entitlement to care" was HIV's energizing issue, given the growing epidemic in the inner cities, and they predicted that "AIDS is going to be seen as part of the larger problem of access to health care in the United States. There is no question about it" (interview number 7). Another gay-activist lawyer argued that legislatures are becoming the important decision sites, because AIDS reveals the shortcomings of the health care system:

The crux of the issue is: How is a private for-profit system going to serve the public needs for health care? AIDS reveals the need for fundamental restructuring as the private health insurance industry has lawfully narrowed its responsibility for AIDS treatment, and, consequently, costs are dumped onto an overburdened public assistance and hospital systems unprepared for AIDS. I think this is ultimately going to be a legislative debate, and what we can do as litigators is play around on the periphery making sure that the (health care) system doesn't act in irrational - or should I say rationally unfair - ways. (Interview number 8) 
Overall, the activist lawyers we interviewed agreed that AIDS was revealing structural deficiencies in the health care system of the United States, and that HIV litigation played only a limited role in the larger issue over economic rights and access to health care that they saw brewing. ${ }^{17}$

JANE HARRIS AIKEN is Professor of Law at the University of South Carolina and is coordinator of the Women and HIV Law Project of USC's pro bono program. She was the former chair of the Arizona Governor's Task Force on AIDS and former director of Arizona State University's HIV Legal Clinic.

MICHAEl MuSheno is Professor of Justice Studies and Public Affairs at Arizona State University, and a member of the Board of Trustees of the Law and Society Association. He was principal investigator of a National Science Foundation (NSF) grant focusing on "AIDS Disputes and Conflict Management," and more recently was Visiting Scientist and Program Director of Law and Social Sciences at NSF. His research focuses on law as a marginalizing force, and the use of law in struggles against marginalization.

\section{NOTES}

1. The "politics of otherness" refers to the use of metaphors and other language that promotes a divided community in response to social problems. Early media references to AIDS as a "gay disease" or a "gay plague" communicated that something was happening outside the general population. Also, the epidemiological category of "risk group" has been popularized in the media such that it creates distance or separates PWAs from the "general population." Overall, a politic of otherness is a cultural politics that prompts people to blame those most affected by social problems and view "them" as a threat to "us" - the general public (see Ross 1988; Sontag 1990).

2. Critical legal scholars take judicial opinions or the calculus of the courts as their starting point and explore the social and cultural norms encoded in these rulings (see Fischl 1987; Tushnet 1984; Unger 1986). They argue that legal doctrines and rights principles do not determine outcomes. Instead, judges use legal discourse to rationalize social norms (Kelman 1987, 3, 86), including "individualism" (i.e., pursuing individual ends as long as doing so respects the ends of others), and "intentionalism" (i.e., individuals are responsible for their behavior). On rare occasions, they use legal discourse to create counter norms or "nontraditional legal presuppositions," including the paired opposites of "altruism" (i.e., the other is as important as self), and "determinism" (i.e., social and cultural conditions shape individual behavior).

Many scholars interested in the power of language to structure disputes have focused on the everyday talk of parties to a dispute and local court personnel (see Merry 1990; Yngvesson 1988). These studies point out that "legal discourse," including talk of rights, is used routinely by laypersons, magistrates, and mediators. In this sense, legal concepts and labels have become embedded in American culture and are actually folkways for voicing grievances and gaining supporters. Simultaneously, these scholars (see Conley \& O'Barr 1990; Merry 1990, 110-33) report across participants, third parties, and audiences on everyday use of a "moral discourse," a language of social responsibilities and obligations, and a "therapeutic discourse," or talk of "behavior as environmentally caused rather than based on individual fault" (Merry 1990, 114). Parties in cases 
use specific language as an attempt to maintain power over a case. However, Merry argues that all parties shift between discourses, particularly when their preferred discourse is not working.

3. Recently, however, this trend has changed. Blood recipients are beginning to win against blood banks and blood product manufacturers. This may be due to a more realistic assessment of the effect that discovery of names and procedures that blood banks use may have on the supply of blood. The blood shield laws appear to provide adequate protection against suits because there is no strict liability for blood suppliers. Negligence must be shown. In the early blood cases, many of which dealt with the need to protect the privacy of donors, limits on discovery made the possibility of a successful claim by a tainted-blood recipient virtually impossible. As courts are becoming more willing to allow some limited discovery, there is a greater potential for awards. Plaintiffs now have the problem of the statute of limitations as a bar to their recovery.

4. Dunn v White (1989), Glick v Henderson (1988), Jarrett v Faulkner (1987), and Muhammad $v$ Carlson (1988) are examples of this trend.

5. See notes 6 and 7 below. One would assume that medical evidence would be a constant in all the cases; instead, its use is a variable, usually determined by the social status of the HIV-positive litigant. While it is true that school children have substantially greater rights than incarcerated persons, these opinions base their conclusions on the medical evidence rather than on the fact that prisoners' rights are severely circumscribed.

6. See, for example, Ray v School District of Desoto County (1987); Doe v Dolton Elementary School District No. 148 (1988).

7. Courts have sustained the exercise of health regulations in other environments where there may be sexual activity, despite evidence that restricting the behavior that was likely to occur in some bookstores and theaters was very unlikely to have an impact on the spread of the virus (see Movie \& Video World, Inc. $v$ Bd. of County Comm'rs of Palm Beach County, Fla. 1989).

8. See Doe $v$ Washington University (1988, 1989); AIDS Litigation Reporter (1988b, 1989a); Doe v National Education Center, Inc. (1988); AIDS Litigation Reporter (1988a, 1989b).

9. This is one interpretation of the outcome of Glover v Eastern Nebraska Community Office of Retardation (1988).

10. This case does not mention HIV. Although Miguel Braschi's lover died of AIDS, the briefs do not mention HIV at all. However, the issue of HIV was clearly implied in this case. Also, due to gay rights organizations' use of the media as part of the broader litigation strategy, the courts were made aware that as more and more gay men died of this disease, claims like the one raised by Miguel Braschi would confront the courts (interview number 5).

11. The appellate court reversed with a single-page, per curiam opinion.

12. When Vincent Chalk walked into his lawyer's office, she knew he would make an effective advocate on the part of people with HIV: "here was Vincent Chalk, driven by the solid principles of his Mormon upbringing, with a sense of commitment to doing something important and valuable" (Slind-Flor 1990, 30).

13. These included the American Medical Association, the State of California, the California Teacher's Association, the Disability Rights and Education Defense Fund, the National Hemophilia Foundation, the Employment Law Center of Legal Aid Society of San Francisco, the Western Law Center for the Handicapped, the Los Angeles Unified School District, and several physicians.

14. In Weaver $v$ Reagen (1989), the AIDS Action Council in its amicus brief to the Eighth Circuit noted that "if the Missouri Medicaid program were to adopt the same approach for cancer as it had for AIDS, possibly as many as half the patients on Medicaid might be deprived of lifesaving treatment." 
15. In a few cases, courts have even held for prisoners with HIV who are seeking reduced sentences or transfers, despite the clear trend of sustaining restrictive actions for prisoners. One New York court decided that "it did not appear that the interest of justice would be substantially served by the defendant's continued prosecution" (People $v$ Camargo 1986, at 991). He was bedridden with AIDS and had a prognosis of death within three or four months. Although the defendant had a previous drug-related conviction, the court found that he did not pose a threat to the safety and welfare of the community.

16. The qualitative analysis of cases revealed such strategies being employed in support of both children and gays pressing HIV claims. We uncovered no effective strategy for enhancing the identity of prisoners pressing HIV-related claims. Moreover, we found very little evidence of third-party support for prisoners and almost no litigation addressing the claims of PWAs of color. When racial minorities appear as litigants to the cases we analyzed, they appear as prisoners or as the criminally accused.

17. While recognizing that present litigation does not address the fundamental flaws in the U.S. health care system, these activist lawyers have sued for access to health care where possible. One of the lawyers, a litigator for a gay rights project of a national civil rights organization, identified a number of out-of-court settlements on his organization's docket that were related to health care access, including Dallas Gay Alliance, Inc. v Dallas City Hospital District (1989). A gay-activist organization, the Dallas Gay Alliance, claimed that Parkland Memorial Hospital discriminated against HIV-positive persons by arbitrarily limiting access to AZT, the only approved drug treatment for HIV at that time; the hospital also limited the number of hospital beds available for persons with HIV and staff for the hospital's AIDS clinic. After a series of ominous legal maneuvers by the plaintiffs, the defendants agreed to correct the practices outlined in the complaint. In discussing the settlement, the litigator noted:

This hospital is typical of overworked urban hospitals that don't have enough health resources to go around. Thus, a crucial issue will be establishing that HIV patients have it worse than all other people approaching these general hospitals for vital services. It was easy to establish in Dallas because the hospital had a ready supply of AZT, but they weren't dispersing it at all or only in trickles. They were trying to keep down the number of HIV patients for fear they would be overwhelmed. (Interview number 9)

\section{REFERENCES}

AIDS LITIGATION REPORTER (1988a) "HIV-Positive Pennsylvania Medical Student Claims Classroom Discrimination," AIDS Litigation Reporter (Andrews Publications, Westtown, Pa.) 29 November: 1804.

- (1988b) "HIV-Infected Dental Student Sues Missouri School over Dismissal," AIDS Litigation Reporter 23 December: 1959-60.

(1989a) "Mo. Dental School Stands by Exclusion of Infected Man from Program," AIDS Litigation Reporter 10 February: 2187-88.

- (1989b) "Philadelphia Man Settles Suit over School Expulsion," AIDS Litigation Reporter 28 April: 2588.

ALTMAN, DENNIS (1987) "Legitimation Through Disaster: AIDS and the Gay Movement." Paper presented at the annual meeting of the American Political Science Association, 3-6 September, Chicago.

BAYER, RONALD (1989) Private Acts, Social Consequences: AIDS and the Politics of Public Health. New York: Free Press. 
BLACK, DONALD (1976) The Behavior of Law. New York: Academic Press. (1984) "Social Control as Dependent Variable." In Toward a General Theory of Social Control. Vol. 1, Fundamentals, edited by D. Black. Orlando, Fla.: Academic Press.

- (1989) Sociological Justice. New York: Oxford Univ. Press.

- (1990) "The Elementary Forms of Conflict Management." In New Directions in the Study of Justice, Law, and Social Control, prepared by School of Justice Studies, Arizona State University. New York: Plenum.

BRANDT, ALlan M. (1987) No Magic Bullet: A Social History of Venereal Diseases in the United States Since 1880. Expanded ed. New York: Oxford Univ. Press.

CENTERS FOR DISEASE CONTROL (CDC) (1991) "Recommendations for Preventing Transmission of Human Immunodeficiency Virus and Hepatitis B Virus to Patients During Exposure-Prone Invasive Procedures," Morbidity and Mortality Weekly Report 40(No. RR-8): 1-9.

CONLEY, JOHN M., and WILLIAM M. O'BARR (1990) Rules versus Relationships: The Ethnography of Legal Discourse. Chicago: Univ. of Chicago Press.

CRIMP, DOUGLAS (1988) “AIDS: Cultural Analysis/Cultural Activism." In AIDS: Cultural Analysis, Cultural Activism, edited by D. Crimp. Cambridge: MIT Press. CRUIKSHANK, MARGARET (1992) The Gay and Lesbiain Liberation Movement. New York: Routledge, Chapman \& Hall.

DANELSKI, DAVID J. (1983) "Law from a Political Perspective," Western Political Quarterly 36: 548-51.

DRASS, KRISS A., and J. WILLIAM SPENCER (1987) "Accounting for Pre-sentencing Recommendations: Typologies and Probation Officers' Theory of Office," Social Problems 34: 277-93.

FEE, ELIZABETH, and DANIEL M. FOX (eds.) (1992) AIDS: The Making of a Chronic Disease. Berkeley: Univ. of California Press.

(1992) "Introduction: The Contemporary Historiography of AIDS." In Fee \& Fox, 1992.

FISCHL, RICHARD MICHAEL (1987) "Some Realism about Critical Legal Studies," University of Miami Law Review 41: 505-32.

GALANTER, MARC (1974) "Why the 'Haves' Come Out Ahead: Speculations on the Limits of Legal Change," Law \& Society Review 9: 95-160.

(1990) "Case Congregations and Their Careers." Law \& Society Review 24: 371-95.

GOSTIN, LARRY (1987) "Traditional Public Health Strategies." In AIDS and the Law: $A$ Guide for the Public, edited by H. Dalton, S. Burris, and the Yale AIDS Law Project. New Haven, Conn.: Yale Univ. Press.

- (1990) "The AIDS Litigation Project - A National Review of Court and Human Rights Commission Decisions, Part II: Discrimination," JAMA: The Journal of the American Medical Association 263: 2086-93.

HENRY, STUART (1985) “Community Justice, Capitalist Society, and Human Agency: The Dialectics of Collective Law in the Cooperative," Law \& Society Review 19: 303-27.

KAIRYS, DAvid (1982) “Introduction." In The Politics of Law: A Progressive Critique, edited by D. Kairys. New York: Pantheon.

KELMAN, MARK (1987) A Guide to Critical Legal Studies. Cambridge: Harvard Univ. Press.

LAUMANN, EDWARD O., and DAVID KNOKE (1987) The Organizational State: Social Choice in National Policy Domains. Madison: Univ. of Wisconsin Press.

LEVI, EDWARD H. (1949) An Introduction to Legal Reasoning. Chicago: Univ. of Chicago Press.

MATHER, LYNN, and BARBARA YNGVESSON (1980-81) "Language Audience and the Transformation of Disputes," Law \& Society Review 15: 775-821.

(C) Basil Blackwell Ltd. 1994 
MCCLAIN, CHARLES (1988) "Of Medicine, Race, and American Law: The Bubonic Plague Outbreak of 1900," Law \& Social Inquiry 13: 447-513.

MERRY, SALLY ENGLE (1988) “Legal Pluralism," Law \& Society Review 22: 869-96. - (1990) Getting Justice and Getting Even: Legal Consciousness Among WorkingClass Americans. Chicago: Univ. of Chicago Press.

NELKIN, DOROTHY, and SANDER L. GILMAN (1988) "Placing Blame for Devastating Disease," Social Research 55: 361-78.

PADGUG, ROBERT A., and GERALD M. OPPENHEIMER (1992) "Riding the Tiger: AIDS and the Gay Community." In Fee \& Fox, 1992.

ROSENBERG, CHARLES E. (1988) "The Definition and Control of Disease - An Introduction," Social Research 55: 327-30.

ROSS, JUDITH WILSON (1988) "Ethics and the Language of AIDS." In AIDS, Ethics and Public Policy, edited by C. Pierce and D. VanDeVeer. Belmont, Calif.: Wadsworth Publishing.

ROTHMAN, DAVID J., and HAROLD EDGAR (1992) "Scientific Rigor and Medical Realities: Placebo Trials in Cancer and AIDS Research." In Fee \& Fox, 1992.

SARAT, AUSTIN (1983) "The Maturation of Political Jurisprudence," Western Political Quarterly 36: 551-58.

SHILTS, RANDY (1987) And the Band Played On: Politics, People, and the AIDS Epidemic. New York: St. Martin's Press.

SLIND-FLOR, VICTORIA (1990) "At the Limits," National Law Journal 27 August: 1.

SMITH, ROGERS M. (1988) "Political Jurisprudence, the 'New Institutionalism,' and the Future of Public Law," American Political Science Review 82: 89-108.

SONTAG, SUSAN (1990) Illness as Metaphor; and, AIDS and Its Metaphors. New York: Doubleday.

TUSHNET, MARK (1984) "Critical Legal Studies and Constitutional Law: An Essay in Deconstruction," Stanford Law Review 36: 623-47.

UNGER, ROBERTO MANGABEIRA (1986) The Critical Legal Studies Movement. Cambridge: Harvard Univ. Press.

WHEELER, STANTON, BLISS CARTWRIGHT, ROBERT A. KAGAN, and LAWRENCE M. FRIEDMAN (1987) "Do the 'Haves' Come Out Ahead? Winning and Losing in State Supreme Courts, 1870-1970." Law \& Society Review 21: 403-45.

YNGVESSON, BARBARA (1988) "Making Law at the Doorway: The Clerk, the Court, and the Construction of Community in a New England Town," Law \& Society Review 22: 409-48.

\section{CASES CITED}

Braschi v Stahl Associates Co., 74 NY2d 201, 544 NYS2d 784, 543 NE2d 49 (1989). Chalk v U.S. District Court for the Central District of California (Orange County Superintendent of Schools), 840 F2d 701 (9th Cir 1987).

City of New York v New Saint Mark's Baths, 130 Misc 2d 911 (Sup Ct New York County), aff'd, 122 AD 2d 747 (1986).

Dallas Gay Alliance, Inc. v Dallas Cty Hospital District, 719 F Supp 1380 (ND Tex 1989).

Doe v Coughlin, 125 AD2d 783, 509 NYS2d 209 (3d Dept 1986), aff'd, 71 NY2d 48, 523 NYS2d 782, 518 NE2d 536 (1987).

Doe v Dolton Elementary School District No. 148, 694 F Supp 440 (ND Ill 1988).

Doe v National Education Center, Inc., No 88-7902 (ED Pa 1988).

Doe $v$ Washington University, No 882-06952 (Mo Cir Ct St Louis County 1988).

Doe $v$ Washington University, 780 F Supp 628 (ED Mo 1991).

Dunn v White, 880 F2d 1188 (10th Cir 1989). 
Glick $v$ Henderson, 855 F2d 536 (8th Cir 1988).

Glover $v$ Eastern Nebraska Community Office of Retardation, 686 F Supp 243

(D Neb 1988), aff'd, 867 F2d 461 (8th Cir), cert. denied 493 US 932, 110 SCt 321, 107 LEd2d 311 (1989).

Jarrett v Faulkner, 662 F Supp 928 (SD Ind 1987).

Judd v Packard, 669 F Supp 741 (D Md 1987).

Leckelt v Board of Commissioners of Hospital District No. 1, 714 F Supp 1377 (ED La 1989).

Martinez by and through Martinez $v$ School Board of Hillsborough County, 692 F Supp 1293 (MD Fla 1988) [Martinez I].

Martinez by and through Martinez $v$ School Board of Hillsborough County, 862 F2d 1502 (11th Cir 1988) [Martinez II].

Martinez by and through Martinez $v$ School Board of Hillsborough County, $711 \mathrm{~F}$ Supp 1066 (MD Fla 1989) [Martinez III].

Movie \& Video World Inc. $v$ Board of County Commissioners of Palm Beach County, Florida, 723 F Supp 695 (SD Fla 1989).

Muhammad v Carlson, 845 F2d 175 (8th Cir 1988).

People v Camargo 135 Misc 2d 987, 516 NYS2d 1004 (Sup Ct New York County 1986).

Powell v Department of Corrections, State of Oklahoma, 647 F Supp 968 (ND Okla 1986).

Ray v School District of Desoto County, 666 F Supp 1524 (MD Fla 1987).

Raytheon Co. v Fair Employment \& Housing Commission, 46 Fair Emp Prac Cases (BNA) 1089 (Super Ct 1988), aff'd, 212 Cal App 3d 1242, 261 Cal Rptr 197 (1989).

School Board of Nassau County v. Arline, 480 US 273, 107 SCt 1123, 94 LEd2d 307 (1987).

Shuttleworth v Broward County, 639 F Supp 654 (SD Fla 1986).

Smith v Emery, 11 AD 10, 42 NYS 258 (2d Dept 1896).

United States v Moore, 669 F Supp 289 (D Minn 1987), aff'd, 846 F2d 1163 (8th Cir 1988).

Weaver $v$ Reagen, 701 F Supp 717 (WD Mo 1988), aff'd as modified, 886 F2d 194 (8th Cir 1989).

Yorkshire Towers Co. v Harpster, 134 Misc 2d, 510 NYS2d 976 (NY Civ Ct 1986), rev'd per curiam, 141 Misc 2d 516, 538 NYS2d 703 (Sup Ct 1988).

\section{LAWS CITED}

Americans With Disabilities Act of 1990, 42 USC $\$ 12101$ et seq. (1988 \& Supp 1991).

Occupational Safety and Health Administration Regulations on Bloodborne Pathogens, 56 Fed Reg 64175-182 (1991) (codified at 29 CFR 1910.1030). 
